\title{
Hyponatremia in Acute Bronchiolitis
}

\author{
Ayse Gultekingil ${ }^{1}$
}

Received: 24 August 2020 / Accepted: 25 November 2020/ Published online: 7 January 2021

(C) Dr. K C Chaudhuri Foundation 2021

To the Editor: In respiratory tract infections, the risk of hyponatremia increases by $29 \%-59 \%$, especially in bronchiolitis patients [1]. Inappropriate antidiuretic hormone (ADH) secretion and decrease of oral intake, vomiting, and incorrect fluid administration can exacerbate the risk $[1,2]$.

The aim of this study is to describe the clinical factors associated with hyponatremia.

Patients diagnosed with acute bronchiolitis between 2014 and 2018 were included. Hyponatremia was described as serum sodium level $<135 \mathrm{mEq} / \mathrm{L}$.

A total of 245 patients were included. The mean serum sodium level was $136.0 \pm 2.23 \mathrm{mEq} / \mathrm{L}$ and hyponatremia was detected in $52(21.2 \%)$ patients. When hyponatremic and normonatremic groups were compared, feeding difficulties and fever were significantly more frequent in the hyponatremic group. The body temperatures of hyponatremic patients at presentation were also significantly higher and their mean oxygen saturations were lower. C-reactive protein (CRP) levels and thrombocyte counts were also higher in the hyponatremic group.

There are two main reasons of hyponatremia in bronchiolitis patients: increased ADH and hypotonic fluid administration. ADH is usually secreted in response to osmolar stimuli, but also secreted in response to other non-osmotic stimuli $[1,2]$. One possible mechanism for this is reduction in left atrial filling due to the hyperinflation of the lungs or a rise in pulmonary vascular resistance, which may also result in hypoxia [3]. In our study, hyponatremic patients had lower oxygen saturation at presentation, supporting this hypothesis.

Ayse Gultekingil

aysegultekingil@gmail.com

1 Department of Pediatrics, Faculty of Medicine, Baskent University, Yukarı Bahçelievler Mahallesi, Mareșal Fevzi Çakmak Cd. No:45, 06490 Çankaya/Ankara, Turkey
Furthermore serum sodium levels and clinical markers of inflammation seem to be correlated, according to our results. Inflammatory mediators seem to play a role in the nonosmotic secretion of ADH, especially TNF- $\alpha$, IL- $1 \beta$, IL-6, and IL-8 $[1,4]$. IL-6 is postulated to play a key role, inflammatory stimuli and IL-6 affect not only anterior pituitary and the hypothalamus-pituitary-adrenal axis but also posterior pituitary hormone secretion, including ADH [4]. Several studies have also shown that IL- 1 and TNF- $\alpha$ reduce epithelial sodium transport by decreasing the expression and function of apical sodium channels and basolateral sodium potassium ATPase [5]. In summary, our results indicate that hyponatremia can be the result of complex nonosmotic regulations and related to inflammatory processes.

Acknowledgements We would like to thank Prof. Dr. Nilgun Erkek for her support in discussion of literature and Dr. Ozge Salor Basaran for proofreading and grammar correction of the article.

\section{Compliance with Ethical Standards}

Conflict of Interest None.

\section{References}

1. Lavagno C, Milani GP, Uestuener P, et al. Hyponatremia in children with acute respiratory infections: a reappraisal. Pediatr Pulmonol. 2017;52(7):962-7.

2. Moritz ML. Syndrome of inappropriate antidiuresis. Pediatr Clin N Am. 2019;66(1):209-26.

3. Rodrigues RM, Schvartsman BG, Farhat SC, et al. Hypotonic solution decreases serum sodium in infants with moderate bronchiolitis. Acta Paediatr. 2014;103(3):e111-5.

4. Swart RM, Hoorn EJ, Betjes MG, et al. Hyponatremia and inflammation: the emerging role of interleukin-6 in osmoregulation. Nephron Physiol. 2011;118(2):45-51.

5. Kreydiyyeh SI, Al-Sadi R. The signal transduction pathway that mediates the effect of interleukin-1 beta on the Na+-K+-ATPase in LLC-PK1 cells. Pflugers Arch. 2004;448(2):231-8.

Publisher's Note Springer Nature remains neutral with regard to jurisdictional claims in published maps and institutional affiliations. 